\title{
Atherogenic dyslipidemia and risk of silent coronary artery disease in asymptomatic patients with type 2 diabetes: a cross-sectional study
}

\author{
Paul Valensi ${ }^{*}$, Antoine Avignon ${ }^{3,4}$, Ariane Sultan ${ }^{3,4}$, Bernard Chanu' ${ }^{1}$, Minh Tuan Nguyen ${ }^{1}$ \\ and Emmanuel Cosson ${ }^{1,2}$ (1)
}

\begin{abstract}
Background: To investigate whether atherogenic dyslipidemia, a dyslipidemic profile combining elevated triglycerides and low high-density lipoprotein (HDL) cholesterol, is predictive of risk of silent myocardial ischemia (SMI) or angiographic coronary artery disease (CAD) in asymptomatic patients with type 2 diabetes.

Methods: Cohort study in 1080 asymptomatic patients with type 2 diabetes with a normal resting electrocardiogram, at least one additional cardiovascular risk factor and low density lipoprotein (LDL) cholesterol $<3.35 \mathrm{mmol} / \mathrm{L}$. Patients initially underwent screening for SMI by stress myocardial scintigraphy. Patients with SMI underwent coronary angiography.

Results: Overall, 60 (5.5 \%) patients had atherogenic dyslipidemia (triglycerides $\geq 2.26 \mathrm{mmol} / \mathrm{L}$ and HDL cholesterol $\leq 0.88 \mathrm{mmol} / \mathrm{L}$ ). In multivariate analyses taking into account the parameters associated in univariate analyses with SMI and then CAD, atherogenic dyslipidemia was associated with SMI (odds ratio 1.8[1.0-3.3]), as were male gender (OR 2.1 [1.5-2.9]), BMI (OR 0.97[0.94-0.997]), retinopathy (OR 1.4[1.1-1.9]), peripheral occlusive arterial disease (POAD: OR 2.5[1.6-3.8]) and mean blood pressure (OR 1.01 [1.00-1.03]); atherogenic dyslipidemia was associated with CAD (OR 4.0[1.7-9.2]), as were male gender (OR 3.0[1.6-5.6]), BMI (OR 0.94[0.90-0.995]), retinopathy (OR 1.7[1.0-2.9], POAD (OR 4.0[2.1-7.4]) and mean blood pressure (OR 1.03[1.01-1.05]). In the subgroup of 584 patients with LDL cholesterol $<2.6 \mathrm{mmol} / \mathrm{L}$, atherogenic dyslipidemia was also associated with CAD (OR 3.6[1.5-9.0]).

Conclusions: Atherogenic dyslipidemia was associated with an increased risk of SMI and silent CAD in patients with type 2 diabetes and LDL cholesterol levels $<3.35 \mathrm{mmol} / \mathrm{L}$. Specific management of atherogenic dyslipidemia might help reducing the high residual burden of cardiovascular disease.
\end{abstract}

Keywords: Silent myocardial ischemia, Diabetes, Residual cardiovascular risk, Atherogenic dyslipidemia, Triglycerides, HDL-cholesterol

\section{Background}

Coronary artery disease (CAD) is the main cause of death and morbidity in patients with type 2 diabetes. However,

\footnotetext{
*Correspondence: paul.valensi@aphp.fr

1 Department of Endocrinology-Diabetology-Nutrition, CRNH-IdF, CINFO,

AP-HP, Jean Verdier Hospital, Université Paris 13, Sorbonne Paris Cité,

Avenue du 14 Juillet, 93143 Bondy Cedex, France

Full list of author information is available at the end of the article
}

symptomatic events represent only a part of this burden, as asymptomatic disease is probably at least as common with a high prevalence of silent myocardial infarction [1] and silent myocardial ischemia (SMI) [2], especially in those with additional cardiovascular risk factors [3-5]. Between one- and two-thirds of the patients with SMI also have angiographic evidence of coronary artery disease (CAD) [3]. SMI is strongly predictive of cardiovascular events and poorer outcomes $[3,6]$ above and 
beyond routine risk predictors [7]. There is a strong need for understanding the risk factors for SMI, which in turn might improve early diagnosis and treatment.

Intensive multifactorial intervention targeting blood pressure, glycemia and low-density lipoprotein (LDL) cholesterol remains the cornerstone of type 2 diabetes management, with a substantial $50 \%$ reduction in the risk of cardiovascular events [8]. However, there is a need to identify patients with residual risk and to target new cardiovascular risk factors. Lipid abnormalities usually persist in statin-treated CAD patients with or without diabetes [9]. High triglycerides levels are associated with high cardiovascular risk [10], the presence of CAD [11] and a higher mortality $[12,13]$. Adjustment for high-density lipoprotein (HDL) cholesterol levels tends to attenuate this association [13]. Alterations in lipid transfers to HDL have been reported in patients with type 2 diabetes and CAD [14]. Further, low HDL cholesterol levels are associated with CAD in patients submitted to coronary angiography [11] as are non-HDL-to-HDL-cholesterol ratio [15] and triglycerides-to-HDL-cholesterol ratio [16] with coronary heart disease in type 2 diabetes.

Higher triglyceride and lower HDL cholesterol levels, considered separately only, were reported in little series of subjects with type 2 diabetes and SMI or silent CAD [17-19]. The combination of elevated triglyceride level and low HDL cholesterol level, commonly named atherogenic dyslipidemia, may therefore be a contributing factor to SMI, in particular in patients with LDL cholesterol in the target range [20-23]. Furthermore, controlling atherogenic dyslipidemia in these patients might improve their cardiovascular prognosis [20,24-26]. Consequently, we made the hypothesis that atherogenic dyslipidemia was associated with SMI and CAD in asymptomatic patients with type 2 diabetes. We also explored the association between non HDL cholesterol and silent myocardial ischemic status.

\section{Methods \\ Patients}

The patients were consecutively recruited between 1991 and 2011 in the diabetes clinics of Jean Verdier Hospital, Bondy and Lapeyronie Hospital, Montpellier, France. The data are retrospective and observational, with no need for either approval by an ethics committee/institutional review board or patients' written informed consent. The patients' records/information are anonymous. Type 2 diabetic patients were included in the cohorts if they were asymptomatic, did not have heart failure, and had a normal 12-lead resting electrocardiogram (ECG), and at least one additional cardiovascular risk factor among dyslipidemia (total cholesterol $>6.5 \mathrm{mmol} / \mathrm{L}$ and/ or LDL-cholesterol $>4.1 \mathrm{mmol} / \mathrm{L}$ and/or HDL-cholesterol
$<0.9 \mathrm{mmol} / \mathrm{L}$ and/or triglycerides $>2.3 \mathrm{mmol} / \mathrm{L}$ and/or lipid lowering medication), hypertension (blood pressure $\geq 140 / 90 \mathrm{mmHg}$ or anti-hypertensive treatment), smoking, nephropathy (urinary albumin excretion rate $>30 \mathrm{mg} /$ day on at least two measurements and/or estimated glomerular filtration rate $<60 \mathrm{~mL} / \mathrm{min}$ ), family history of premature CAD (before the age of 60 in firstdegree relatives), peripheral occlusive arterial disease (POAD: stenosis measured $\geq 50 \%$ by ultrasound examination). Patients with a history of valvular heart disease, congenital heart disease or cardiomyopathy, or symptomatic CAD were excluded. In this study, we selected the patients with LDL cholesterol levels $<3.35 \mathrm{mmol} / \mathrm{L}$, which was the target range before 2000 . We also selected a subgroup with LDL cholesterol values $<2.6 \mathrm{mmol} / \mathrm{L}$, with or without lipid-modifying treatment.

\section{Methods}

At baseline, clinical examination was performed and the presence of diabetic complications (retinopathy, nephropathy, peripheral neuropathy, POAD) was assessed. Patients initially underwent screening for type 1 SMI by ${ }^{201}$ thallium myocardial scintigraphy after an ECG stress test, a pharmacological stress test (dipyridamole injection), or both, as previously reported [3, 7, 27]. ECG stress test was performed when the patient was able to exercise on a bicycle ergometer and was expected to have an interpretable exercise ECG. If the patient was unable to exercise or when the ECG stress test result was indeterminate, a pharmacological stress test was performed. SMI was defined by evidence of an abnormal ECG stress test and/ or abnormal myocardial scintigraphy imaging (i.e., defects in at least 3 out of 17 segmental regions). The patients with SMI were subsequently screened for angiographic coronary artery disease. CAD was defined as $\geq 70 \%$ narrowing of the luminal diameter in the left anterior descending artery, the circumflex artery, a well-developed marginal vessel or the right coronary artery or $\geq 50 \%$ narrowing of the left main coronary artery diameter. The patients with SMI but who did not undergo a coronary angiography were not considered in analyzing the factors associated with CAD.

Blood samples were taken for measurement of $\mathrm{HbA1c}$ (Dimension ${ }^{\circledR}$ technology, Siemens Healthcare Diagnosis Inc., Newark, USA), serum total and HDL cholesterol and triglycerides (enzymatic colorimetry, Hitachi 912, Roche Diagnostics, Meylan, France), serum creatinine (colorimetry, Kone Optima, Thermolab System, Paris La Défense, France). Urine samples were collected for measurement of 24-h proteinuria and 24-h urinary albumin excretion rate (laser immunonephelometry, BN100, Dade-Behring, Paris, France). LDL cholesterol was calculated according to the Friedewald formula and glomerular filtration rate 
was estimated using the Modification of Diet in Renal Disease (MDRD) Study equation. Atherogenic dyslipidemia was defined in accordance with the criteria used in the ACCORD Lipid study [20] as the combination of low plasma levels of HDL cholesterol $(\leq 0.88 \mathrm{mmol} / \mathrm{L}$ $[34 \mathrm{mg} / \mathrm{dL}])$ and elevated triglycerides $(\geq 2.26 \mathrm{mmol} / \mathrm{L})$ [204 mg/dL]. Non HDL cholesterol was also calculated. Apoproteins A1 and B were measured in the population of Bondy center (immunoturbidimetry, COBAS 6000, Roche Diagnostics, Meylan, France).

\section{Statistical analyses}

We hypothesized that the presence of atherogenic dyslipidemia would be associated with an increased risk for SMI or silent CAD. This was first investigated for the patients with $\mathrm{LDL}$ cholesterol $<3.35 \mathrm{mmol} / \mathrm{L}$ and then in the subgroup of patients with LDL cholesterol below the target value $(<2.6 \mathrm{mmol} / \mathrm{L})$. No data replacement procedure was used for missing data. Continuous variables were expressed as mean \pm SD and compared by one-way ANOVA or the Mann-Whitney's $U$ test as adequate. The significance of differences in proportions was tested with the $\chi^{2}$ test. Logistic regression was used for multivariate analyses based on models including the factors that were associated with silent coronary status with a $\mathrm{p}$ value $\leq 0.10$ in univariate analyses. Odds ratios with $95 \%$ confidence intervals $(95 \% \mathrm{CI}$ ) for the risk of SMI or CAD were reported. We calculated the Hosmer-Lemeshow $X^{2}$ statistic $\left(H L X^{2}\right)$ to test the goodness of fit between expected and observed probabilities of an event in the different models. Statistical analyses were carried out using SPSS software (SPSS, Chicago, IL). The level of significance for all tests was $\mathrm{p}<0.05$.

\section{Results}

\section{Patient characteristics}

A total of 1623 patients with type 2 diabetes were screened for SMI. We selected 1080 patients who had LDL cholesterol levels $<3.35 \mathrm{mmol} / \mathrm{L}$. Their baseline characteristics are summarized in Table 1 . Overall, patients had longstanding diabetes (mean 13.8 years), with a high a priori cardiovascular risk: hypertension (76.3\%), nephropathy (57.3\%), smoking habits (22.8\%), familial history of premature CAD (13.0 \%) and POAD (11.3\%). LDL cholesterol was $2.4 \pm 0.6 \mathrm{mmol} / \mathrm{L}$. The 543 patients who were not included had significantly higher HbAlc $(8.9 \pm 2.5 \%$; $74 \pm 8 \mathrm{mmol} / \mathrm{mol}$ ), more dyslipidemia $(72.1 \%)$ and less nephropathy (30.8\%) and statin treatment (25.0\%), with no difference for other parameters (Table 2). Finally, 584 patients $(5.4 \%)$ had baseline LDL cholesterol levels below the target value $(<2.6 \mathrm{mmol} / \mathrm{L})$.

Atherogenic dyslipidemia was diagnosed in 60 (5.6\%) patients with LDL $<3.35 \mathrm{mmol} / \mathrm{L}$ (Table 1) and in 35
(6.0 \%) patients with $\mathrm{LDL}<2.6 \mathrm{mmol} / \mathrm{L}$ (Table 3). In the study population, patients with atherogenic dyslipidemia had significantly higher mean total cholesterol and triglyceride levels, lower mean HDL cholesterol levels, higher non HDL cholesterol and lower apoprotein A1 levels, but did not differ significantly for the other characteristics from those without atherogenic dyslipidemia (Table 1). In the subgroup with LDL cholesterol $<2.6 \mathrm{mmol} / \mathrm{L}$, patients with atherogenic dyslipidemia were younger, had higher BMI, HbAlc and total cholesterol, a shorter diabetes duration and lower LDL cholesterol compared to patients without atherogenic dyslipidemia. They were also more likely treated by fibrate (Table 3).

\section{Stress tests results}

In the total cohort, SMI was identified in 292 (27 \%) patients. Among them, 218 subsequently underwent a coronary angiography, and CAD was confirmed in 91 patients $(8.4 \%$ of the total study population of 1080 patients and $41.7 \%$ of the patients with SMI).

In the subgroup of 584 patients with $\mathrm{LDL}<2.6 \mathrm{mmol} / \mathrm{L}$, SMI was diagnosed in 155 patients (26.5\%). Coronary angiography was performed in 112 subjects and CAD was confirmed in 45 patients.

\section{Parameters associated with silent myocardial ischemia}

Table 4 shows that male gender, lower body mass index, retinopathy, POAD, higher mean blood pressure, smoking and atherogenic dyslipidemia including lower HDL cholesterol level were associated with SMI. In multivariate analyses taking into account all these parameters but HDL cholesterol, SMI was independently associated with atherogenic dyslipidemia (odds ratio 1.8 [95\% confidence interval 1.0-3.3], $\mathrm{p}<0.05$ ) (Table 5). In the subgroup of 584 patients with $\mathrm{LDL}<2.6 \mathrm{mmol} / \mathrm{L}$, SMI was no longer associated with atherogenic dyslipidemia (prevalence in patients with vs without SMI: 7.7 vs $5.4 \%, \mathrm{p}=0.323$ ).

\section{Parameters associated with silent coronary artery disease} Male gender, lower body mass index, retinopathy, microalbuminuria, POAD, higher mean blood pressure, smoking and atherogenic dyslipidemia including lower HDL cholesterol and higher triglyceride levels, higher nonHDL cholesterol and apoprotein B levels were associated with silent CAD (Table 4). In multivariate analyses taking into account all these parameters but HDL cholesterol, triglycerides levels, non-HDL cholesterol and apoprotein $\mathrm{B}$; silent $\mathrm{CAD}$ was independently associated with atherogenic dyslipidemia (OR 4.0 [1.7-9.2], $\mathrm{p}<0.001$ ) (Table 5).

In patients with $\mathrm{LDL}<2.6 \mathrm{mmol} / \mathrm{L}, \mathrm{CAD}$ was associated with male gender (OR 4.7 [1.9-11.2], $\mathrm{p}<0.0001$ ), lower body mass index $(\mathrm{p}<0.01)$, POAD (OR 5.3 
Table 1 Patients' characteristics according to the presence or absence of atherogenic dyslipidemia

\begin{tabular}{|c|c|c|c|c|}
\hline & $\begin{array}{l}\text { Total } \\
n=1080\end{array}$ & $\begin{array}{l}\text { No atherogenic } \\
\text { dyslipidemia } \\
n=1020\end{array}$ & $\begin{array}{l}\text { Atherogenic } \\
\text { dyslipidemia } \\
n=60\end{array}$ & $\mathrm{p}$ \\
\hline \multicolumn{5}{|l|}{ Clinical characteristics } \\
\hline Age, years & $61.6 \pm 9.0$ & $61.7 \pm 9.1$ & $59.7 \pm 8.2$ & 0.09 \\
\hline Gender, male/female & $614 / 466$ & $577 / 443$ & $37 / 23$ & 0.44 \\
\hline Body mass index, $\mathrm{kg} / \mathrm{m}^{2}$ & $30.2 \pm 5.9$ & $30.2 \pm 6.0$ & $31.1 \pm 4.9$ & 0.23 \\
\hline Waist circumference, $\mathrm{cm}$ & $104 \pm 13$ & $104 \pm 13$ & $107 \pm 10$ & 0.37 \\
\hline \multicolumn{5}{|l|}{ Diabetes } \\
\hline Diabetes duration, years & $13.8 \pm 8.5$ & $13.9 \pm 8.6$ & $11.8 \pm 6.9$ & 0.07 \\
\hline $\mathrm{HbA} 1 \mathrm{c}, \%$ & $8.5 \pm 1.8$ & $8.4 \pm 1.8$ & $8.6 \pm 2.0$ & 0.42 \\
\hline $\mathrm{HbA} 1 \mathrm{c}, \mathrm{mmol} / \mathrm{mol}$ & $69 \pm 6$ & $68 \pm 6$ & $70 \pm 7$ & 0.42 \\
\hline Retinopathy, \% & $357(34.2)$ & $341(34.7)$ & $16(27.1)$ & 0.24 \\
\hline Nephropathy, \% & $406(57.3)$ & $383(57.5)$ & $23(53.5)$ & 0.61 \\
\hline Peripheral arterial occlusive disease, $\%$ & $119(11.3)$ & $110(11.1)$ & $9(15.8)$ & 0.27 \\
\hline \multicolumn{5}{|l|}{ Additional cardiovascular risk factors } \\
\hline Family history of premature $C A D, \%$ & $137(13.0)$ & $126(12.7)$ & $11(19.0)$ & 0.16 \\
\hline Hypertension, \% & $402(76.3)$ & $376(76.3)$ & $26(76.5)$ & 0.98 \\
\hline \multicolumn{5}{|l|}{ Lipid parameters } \\
\hline Total cholesterol, mmol/L & $4.5 \pm 0.7$ & $4.5 \pm 0.7$ & $4.7 \pm 0.7$ & $<0.05$ \\
\hline $\mathrm{HDL}$ cholesterol, mmol/L & $1.3 \pm 0.5$ & $1.3 \pm 0.5$ & $0.8 \pm 0.1$ & $<0.0001$ \\
\hline Triglycerides, mmol/L & $1.7 \pm 1.0$ & $1.6 \pm 0.8$ & $3.4 \pm 1.1$ & $<0.0001$ \\
\hline LDL cholesterol, mmol/L & $2.4 \pm 0.6$ & $2.4 \pm 0.6$ & $2.4 \pm 0.6$ & 0.27 \\
\hline Non HDL cholesterol, mmol/L & $3.2 \pm 0.7$ & $3.1 \pm 0.7$ & $3.9 \pm 0.7$ & $<0.0001$ \\
\hline Apoprotein A1, g/L & $1.47 \pm 0.74$ & $1.49 \pm 0.28$ & $1.10 \pm 0.12$ & $<0.0001$ \\
\hline Apoprotein B, g/L & $0.89 \pm 0.18$ & $0.89 \pm 0.18$ & $1.10 \pm 0.12$ & 0.06 \\
\hline Fibrate treatment, \% & $96(9.1)$ & $87(8.7)$ & $9(15.8)$ & 0.09 \\
\hline Statin treatment, \% & $438(41.4)$ & $415(41.5)$ & $23(40.4)$ & 0.87 \\
\hline Smoking, \% & $245(22.8)$ & $226(22.3)$ & $19(32.2)$ & 0.08 \\
\hline
\end{tabular}

Data are $\mathrm{n}(\%)$ or mean $\pm \mathrm{SD}$

CAD coronary artery disease

[2.6-10.7]), higher mean blood pressure $(\mathrm{p}<0.05)$, atherogenic dyslipidemia (prevalence in patients with vs without CAD 15.6 vs $4.8 \%$, OR 3.6 [1.5-9.0], $\mathrm{p}=0.01$ ) including HDL cholesterol ( $\mathrm{p}<0.01$ ), and smoking (OR $2.7[1.5-5.1], \mathrm{p}<0.001)$; with a trend for retinopathy $(\mathrm{p}=0.09)$ (Table 6). Multivariate analysis taking into account these parameters but HDL-cholesterol showed that atherogenic dyslipidemia was not significantly associated $(\mathrm{p}=0.057)$ with silent CAD in patients with $\mathrm{LDL}$ $<2.6 \mathrm{mmol} / \mathrm{L}$ (Table 5).

Finally, the association between atherogenic dyslipidemia and silent CAD was only shown for patients with LDL cholesterol $<3.35 \mathrm{mmol} / \mathrm{L}$ (Fig. 1).

\section{Discussion}

The results of this cohort study show that atherogenic dyslipidemia is significantly and independently associated with asymptomatic CAD in patients with type 2 diabetes, especially those with LDL cholesterol below
$3.35 \mathrm{mmol} / \mathrm{L}$. Figure 1 again illustrates the potential role of atherogenic dyslipidemia in the residual cardiovascular risk. These findings are strengthened by the size of the cohort and consistency with other reports for the prevalence of SMI in this setting $[3,7,27]$.

\section{Prevalence of atherogenic dyslipidemia}

The prevalence of atherogenic dyslipidemia was lower than anticipated from the ACCORD Lipid study population (17\%), which was also characterized by longstanding diabetes and LDL cholesterol levels in the target range [20]. This was not unexpected. First the ACCORD Lipid study defined the subgroup with atherogenic dyslipidemia using tertile analysis [20], with thresholds that were different from the tertiles in our cohort: $0.88 \mathrm{mmol} / \mathrm{L}$ in ACCORD and $1.07 \mathrm{mmol} / \mathrm{L}$ in our series for HDL cholesterol, and 2.26 and $1.86 \mathrm{mmol} / \mathrm{L}$ respectively for triglycerides. Second, high triglycerides and low HDL cholesterol are biologically associated [23]. An 
Table 2 Characteristics of the patients who were included (LDL cholesterol $<3.35 \mathrm{mmol} / \mathrm{L}$ ) or not (LDL cholesterol $\geq 3.35 \mathrm{mmol} / \mathrm{L}$ ) in the study

\begin{tabular}{|c|c|c|c|}
\hline & $\begin{array}{l}\text { Included patients } \\
n=1080\end{array}$ & $\begin{array}{l}\text { Excluded patients } \\
n=543\end{array}$ & $\mathrm{p}$ \\
\hline \multicolumn{4}{|l|}{ Clinical characteristics } \\
\hline Age, years & $61.6 \pm 9.0$ & $60.3 \pm 9.2$ & 0.09 \\
\hline Gender, male/female & $614 / 466$ & $291 / 252$ & 0.21 \\
\hline Body mass index, $\mathrm{kg} / \mathrm{m}^{2}$ & $30.2 \pm 5.9$ & $30.3 \pm 6.4$ & 0.786 \\
\hline \multicolumn{4}{|l|}{ Diabetes } \\
\hline Diabetes duration, years & $13.8 \pm 8.5$ & $13.7 \pm 3.7$ & 0.838 \\
\hline $\mathrm{HbA} 1 \mathrm{c}, \%$ & $8.5 \pm 1.8$ & $8.9 \pm 2.5$ & $<0.001$ \\
\hline Retinopathy, \% & $357(34.2)$ & $180(34.0)$ & 0.94 \\
\hline Nephropathy, \% & $406(57.3)$ & $181(30.8)$ & $<0.001$ \\
\hline Peripheral neuropathy, \% & $233(13.9)$ & $139(45.4)$ & 0.71 \\
\hline Peripheral arterial occlusive disease, $\%$ & $119(11.3)$ & $56(10.4)$ & 0.58 \\
\hline Family history of premature $C A D, \%$ & $137(13.0)$ & $69(13.4)$ & 0.83 \\
\hline \multicolumn{4}{|l|}{ Additional cardiovascular risk factors } \\
\hline Hypertension, \% & $402(76.3)$ & $235(72.8)$ & 0.25 \\
\hline Dyslipidemia, \% & $244(65.3)$ & $246(72.1)$ & $<0.01$ \\
\hline \multicolumn{4}{|l|}{ Lipid parameters } \\
\hline $\mathrm{HDL}$ cholesterol, mmol/L & $1.3 \pm 0.5$ & $1.2 \pm 0.4$ & 0.001 \\
\hline Triglycerides, $\mathrm{mmol} / \mathrm{L}$ & $1.7 \pm 1.0$ & $1.9 \pm 1.0$ & $<0.001$ \\
\hline LDL cholesterol, mmol/L & $2.4 \pm 0.6$ & $4.1 \pm 0.7$ & $<0.001$ \\
\hline Non-HDL cholesterol, mmol/L & $3.2 \pm 0.7$ & $4.9 \pm 0.9$ & $<0.0001$ \\
\hline Apoprotein A1, g/L & $1.47 \pm 0.29$ & $1.50 \pm 0.30$ & 0.506 \\
\hline Apoprotein B, g/L & $0.89 \pm 0.18$ & $1.31 \pm 0.23$ & $<0.0001$ \\
\hline Fibrate treatment, \% & $96(9.1)$ & $61(11.8)$ & 0.085 \\
\hline Statin treatment, \% & $438(41.4)$ & $129(25.0)$ & $<0.001$ \\
\hline Smoking, \% & $245(22.8)$ & $135(25.1)$ & 0.30 \\
\hline
\end{tabular}

CAD coronary artery disease

analysis of the ACCORD Lipid study suggested a more conservative estimate of $\sim 10 \%$ [28]. In a population of subjects with diabetes from Europe and Canada treated by statins, the rate of patients with both LDL cholesterol below target value $(<2.6 \mathrm{mmol} / \mathrm{L})$ and low HDL cholesterol plus elevated triglycerides was $6 \%$ [29]. Thus, the current study provides a more accurate estimation of the true prevalence of this dyslipidemic profile in a real-life clinical setting, in which a substantial proportion of highrisk patients with type 2 diabetes was treated with statins.

\section{Association between atherogenic dyslipidemia and SMI}

We show here for the first time an association between atherogenic dyslipidemia and silent CAD. This association was found in individuals with type 2 diabetes and LDL cholesterol lower than $3.35 \mathrm{mmol} / \mathrm{L}$ with a borderline significance for those with LDL cholesterol lower than $2.6 \mathrm{mmol} / \mathrm{L}$. The role of atherogenic dyslipidemia on incident cardiovascular events is well-known [30-32] but to our knowledge, few studies have previously reported an association between atherogenic dyslipidemia and prevalent cardiovascular diseases, such an association between a high triglyceride-to-HDL cholesterol ratio and left ventricular geometry in children [33] and CAD in type 2 diabetes [16]. Atherogenic dyslipidemia has also been reported to be usual in Indian patients with proven CAD [34]. Some studies have reported an association between high levels of triglycerides and SMI $[17,18]$ and CAD [18]; and between low levels of HDL-cholesterol and CAD [19]. However, these observations were not analyzed according to the combination of lipid parameters, statin and/or fibrate treatments, or LDL cholesterol levels. This appears to be important as our data did not show any association between atherogenic dyslipidemia and SMI in patients with LDL cholesterol above $3.35 \mathrm{mmol} / \mathrm{L}$ (Fig. 1). Atherogenic dyslipidemia might therefore contribute to residual cardiovascular risk in type 2 diabetes. Altogether, considering atherogenic dyslipidemia as a marker or a risk factor for SMI and silent CAD should be limited to the patients with controlled 
Table 3 Characteristics of the patients with LDL cholesterol $<2.6 \mathrm{mmol} / \mathrm{L}$ according to the presence of atherogenic dyslipidemia

\begin{tabular}{|c|c|c|c|}
\hline & $\begin{array}{l}\text { No atherogenic dysplipidemia } \\
n=549\end{array}$ & $\begin{array}{l}\text { Atherogenic dysplipidemia } \\
\mathrm{n}=35\end{array}$ & $\mathrm{p}$ \\
\hline \multicolumn{4}{|l|}{ Clinical characteristics } \\
\hline Age, years & $61.6 \pm 9.0$ & $60.6 \pm 7.4$ & 0.001 \\
\hline Gender, male/female & $334 / 215$ & $24 / 11$ & 0.36 \\
\hline Body mass index, $\mathrm{kg} / \mathrm{m}^{2}$ & $30.1 \pm 6.0$ & $31.0 \pm 5.0$ & 0.001 \\
\hline \multicolumn{4}{|l|}{ Diabetes } \\
\hline Diabetes duration, years & $14.0 \pm 8.4$ & $12.0 \pm 7.3$ & 0.003 \\
\hline $\mathrm{HbA} 1 \mathrm{c}, \%$ & $8.4 \pm 1.9$ & $9.0 \pm 2.0$ & 0.006 \\
\hline Retinopathy, \% & $180(34.0)$ & $10(26.8)$ & 0.51 \\
\hline Nephropathy, \% & $212(60.1)$ & $16(69.6)$ & 0.37 \\
\hline Peripheral neuropathy, \% & $111(45.9)$ & $10(58.8)$ & 0.30 \\
\hline Peripheral arterial occlusive disease, $\%$ & $59(11.2)$ & $6(18.2)$ & 0.22 \\
\hline Family history of premature $C A D, \%$ & $67(12.5)$ & $8(23.5)$ & 0.07 \\
\hline \multicolumn{4}{|l|}{ Additional cardiovascular risk factors } \\
\hline Hypertension, \% & $207(80.5)$ & $13(72.2)$ & 0.39 \\
\hline \multicolumn{4}{|l|}{ Lipid parameters } \\
\hline Total cholesterol, $\mathrm{mmol} / \mathrm{L}$ & $4.1 \pm 0.6$ & $4.4 \pm 0.7$ & 0.013 \\
\hline HDL cholesterol, mmol/L & $1.4 \pm 0.5$ & $0.8 \pm 0.1$ & 0.073 \\
\hline Triglycerides, mmol/L & $1.5 \pm 0.9$ & $3.7 \pm 1.3$ & 0.24 \\
\hline LDL cholesterol, mmol/L & $2.0 \pm 0.4$ & $1.9 \pm 0.4$ & 0.003 \\
\hline Non-HDL cholesterol, mmol/L & $2.7 \pm 0.6$ & $3.6 \pm 0.7$ & $<0.0001$ \\
\hline Apoprotein A1, g/L & $1.47 \pm 0.29$ & $1.13 \pm 0.13$ & 0.001 \\
\hline Apoprotein B, g/L & $0.79 \pm 0.16$ & $0.91 \pm 0.14$ & 0.045 \\
\hline Fibrate treatment, \% & $41(7.6)$ & $6(17.6)$ & $<0.05$ \\
\hline Statin treatment, $\%$ & $279(52.1)$ & $15(44.1)$ & 0.37 \\
\hline Smoking, \% & $126(23.1)$ & $12(34.2)$ & 0.13 \\
\hline
\end{tabular}

CAD coronary artery disease

LDL cholesterol. However, this might have therapeutic implications.

\section{Therapeutic implications}

Whether the identification of patients with diabetes and SMI may reduce their cardiovascular risk has been debated [6, 35-37]. However, treating atherogenic dyslipidemia was never considered in these studies. Based on our findings, we propose that targeting atherogenic dyslipidemia might help to reduce the residual risk of asymptomatic CAD. In support, an analysis of the Fenofibrate Intervention and Event Lowering in Diabetes (FIELD) study showed that treatment with fenofibrate (which lowers triglycerides and raises HDL cholesterol) led to a $78 \%$ reduction in subsequent cardiovascular events in patients with silent myocardial infarction $(\mathrm{p}=0.0003)$ [38]. Additionally, in the Diabetes Atherosclerosis Intervention Study (DAIS), fenofibrate reduced progression of CAD in patients with type 2 diabetes, about $50 \%$ of them having clinical disease [25]. A treatment with fenofibrate versus placebo added to statin therapy in patients with type 2 diabetes was associated with a $30 \%$ reduction of cardiovascular events in subjects with atherogenic dyslipidemia as defined as in our cohort [20]. Further evidence supporting the clinical benefits of fibrate-based therapy in patients with atherogenic dyslipidemia was provided by a meta-analysis of five placebo-controlled studies, which showed that fibrate use was associated with a $35 \%$ reduction in the risk of coronary events [39]. Long-term mortality was also shown to be reduced in patients with CAD who were initially allocated to bezafibrate versus placebo and this effect was more prominent in those with triglyceride levels $\geq 200 \mathrm{mg} / \mathrm{dL}$ [26]. In the patients with atherogenic dyslipidemia, achieving target non-HDL cholesterol levels should be a key focus of cardio-vascular risk management [40]. Non-HDL cholesterol is well defined as a secondary target in the treatment of dyslipidemias in the European Atherosclerosis Society/European Society of 
Table 4 Patients' characteristics according to the presence or absence of silent myocardial ischemia or silent coronary artery disease in patients with $\mathrm{LDL}<3.35 \mathrm{mmol} / \mathrm{L}$

\begin{tabular}{|c|c|c|c|c|c|c|c|c|}
\hline & $\begin{array}{l}\text { No SMI } \\
n=788\end{array}$ & $\begin{array}{l}\text { SMI } \\
n=292\end{array}$ & $\begin{array}{l}\text { Odds ratio }{ }^{a} \\
{[95 \mathrm{Cl}]}\end{array}$ & $p$ & $\begin{array}{l}\text { No CAD } \\
n=909\end{array}$ & $\begin{array}{l}\text { CAD } \\
n=91\end{array}$ & $\begin{array}{l}\text { Odds ratiob } \\
\text { [95Cl] }\end{array}$ & $\mathbf{p}$ \\
\hline \multicolumn{9}{|l|}{ Clinical characteristics } \\
\hline Age, years & $61.6 \pm 9.2$ & $61.5 \pm 8.6$ & & 0.90 & $61.4 \pm 9.0$ & $61.5 \pm 8.7$ & & 0.93 \\
\hline Gender, male/female & $405 / 383$ & $209 / 83$ & $2.4[1.8-3.2]$ & $<0.0001$ & $486 / 423$ & $73 / 18$ & $3.5[2.1-6.0]$ & $<0.0001$ \\
\hline Body mass index, $\mathrm{kg} / \mathrm{m}^{2}$ & $30.6 \pm 6.2$ & $29.1 \pm 5.1$ & & $<0.0001$ & $30.5 \pm 6.1$ & $28.4 \pm 4.4$ & & $<0.01$ \\
\hline \multicolumn{9}{|l|}{ Diabetes } \\
\hline Diabetes duration, years & $13.8 \pm 8.5$ & $13.5 \pm 8.6$ & & 0.56 & $13.8 \pm 8.4$ & $13.0 \pm 8.5$ & & 0.39 \\
\hline $\mathrm{HbA} 1 \mathrm{c}, \%$ & $8.4 \pm 1.8$ & $8.5 \pm 2.0$ & & 0.43 & $8.5 \pm 1.8$ & $8.5 \pm 2.1$ & & 0.95 \\
\hline $\mathrm{HbA} 1 \mathrm{c}, \mathrm{mmol} / \mathrm{mol}$ & $64 \pm 6$ & $65 \pm 6$ & & 0.43 & $66 \pm 6$ & $65 \pm 6$ & & 0.95 \\
\hline Retinopathy, \% & 243 (31.9) & $114(40.4)$ & $1.4[1.1-1.9]$ & 0.01 & $290(33.0)$ & $41(46.6)$ & $1.8[1.1-2.8]$ & $<0.05$ \\
\hline Nephropathy, \% & $294(57.6)$ & $112(56.3)$ & & 0.74 & $340(56.2)$ & $36(56.3)$ & & 0.99 \\
\hline $\begin{array}{l}\text { Microalbuminuria }>30 \text { mg/ } \\
\text { day, \% }\end{array}$ & $205(30.3)$ & $88(35.1)$ & & 0.17 & $242(30.9)$ & $35(43.2)$ & $1.7[1.1-2.7]$ & $<0.05$ \\
\hline $\begin{array}{l}\text { Peripheral arterial occlusive } \\
\text { disease, } \%\end{array}$ & $60(7.9)$ & $59(20.6)$ & $3.0[2.1-4.5]$ & $<0.0001$ & $75(8.5)$ & $23(25.8)$ & $3.8[2.2-6.4]$ & $<0.0001$ \\
\hline \multicolumn{9}{|l|}{ Additional cardiovascular risk factors } \\
\hline Hypertension, \% & $248(74.3)$ & $154(79.8)$ & & 0.15 & $331(75.2)$ & $60(81.1)$ & & 0.27 \\
\hline Mean blood pressure, mmHg & $92 \pm 11$ & $94 \pm 13$ & & $<0.01$ & $92 \pm 12$ & $97 \pm 13$ & & $<0.0001$ \\
\hline Atherogenic dyslipidemia, \% & $36(4.6)$ & $24(8.2)$ & $1.9[1.1-3.2]$ & $<0.05$ & $278(61.6)$ & $57(75.0)$ & $1.9[1.1-3.2]$ & $<0.05$ \\
\hline \multicolumn{9}{|l|}{ Lipid parameters } \\
\hline HDL cholesterol, mmol/L & $1.3 \pm 0.5$ & $1.2 \pm 0.4$ & & $<0.01$ & $1.3 \pm 0.5$ & $1.1 \pm 0.4$ & & $<0.0001$ \\
\hline Triglycerides, mmol/L & $1.7 \pm 1.0$ & $1.7 \pm 0.9$ & & 0.48 & $1.7 \pm 1.0$ & $1.9 \pm 1.1$ & & $<0.01$ \\
\hline LDL cholesterol, mmol/L & $2.4 \pm 0.6$ & $2.4 \pm 0.6$ & & 0.97 & $2.4 \pm 0.6$ & $2.5 \pm 0.6$ & & 0.34 \\
\hline Non HDL cholesterol, mmol/L & $3.2 \pm 0.7$ & $3.2 \pm 0.7$ & & 0.637 & $3.2 \pm 0.7$ & $3.3 \pm 0.7$ & & 0.05 \\
\hline Apoprotein A1, g/L & $1.47 \pm 0.29$ & $1.47 \pm 0.25$ & & 0.958 & $1.48 \pm 0.29$ & $1.39 \pm 0.22$ & & 0.195 \\
\hline Apoprotein B, g/L & $0.89 \pm 0.19$ & $0.92 \pm 0.18$ & & 0.205 & $0.89 \pm 0.19$ & $1.03 \pm 0.15$ & & 0.002 \\
\hline Fibrate treatment, $\%$ & $67(8.7)$ & $29(10.2)$ & & 0.45 & $76(8.5)$ & $11(12.2)$ & & 0.24 \\
\hline Statin treatment, \% & $316(40.9)$ & $122(42.8)$ & & 0.57 & $365(41.0)$ & $39(43.3)$ & & 0.66 \\
\hline Smoking, \% & $163(20.8)$ & $82(28.3)$ & $1.5[1.1-2.0]$ & 0.01 & $196(21.7)$ & $32(35.2)$ & $2.0[1.2-3.1]$ & $<0.01$ \\
\hline
\end{tabular}

Data are nn or mean \pm SD

$C A D$ coronary artery disease, $S M I$ silent myocardial ischemia, $95 \mathrm{Cl}$ confidence interval at $95 \%$

a Odds ratio comparing patients with SMI to those without

b Odds ratio comparing the patients with CAD to those without

Cardiology (EAS/ESC) guidelines, which set a specific target $0.8 \mathrm{mmol} / \mathrm{L}$ higher than the corresponding $\mathrm{LDL}$ cholesterol target value [41]. Such was the case in our subpopulation with silent CAD in which subjects had non-HDL cholesterol level $0.88 \mathrm{mmol} / \mathrm{L}$ higher than LDL cholesterol (Table 4). Non-HDL cholesterol, and similarly apoprotein $\mathrm{B}$, were associated with an increased risk of silent CAD. Therefore, non-HDL cholesterol should be an additional target in this very high-risk population.

\section{Limitations}

We acknowledge a number of limitations to this study. These include the observational design of the study, which cannot show a causal relationship but only an association between atherogenic dyslipidemia and SMI, the inclusion of inpatients and a low prevalence of atherogenic dyslipidemia. Mean LDL cholesterol level in our series was $2.4 \mathrm{mmol} / \mathrm{L}$ but the absolute number of patients with atherogenic dyslipidemia who had LDL cholesterol level strictly below the target value of $2.6 \mathrm{mmol} / \mathrm{L}$ was low. Furthermore, only $41 \%$ of the patients were treated with statin, which is nowadays routinely prescribed in patients with type 2 diabetes. However, we report one of the largest ever-published series of asymptomatic patients with type 2 diabetes, and known CAD status, although some patients with SMI did not undergo a coronary angiography. Despite these limits, the results of the study suggest that atherogenic dyslipidemia might be a contributing 
Table 5 Parameters explaining silent myocardial ischemia and coronary artery disease in multivariate analyses

\begin{tabular}{|c|c|c|c|}
\hline & Odds ratio & $\begin{array}{l}95 \% \text { confidence } \\
\text { interval }\end{array}$ & $p$ \\
\hline \multicolumn{4}{|c|}{$\begin{array}{l}\text { Silent myocardial ischemia in patients with } \mathrm{LDL}<3.35 \mathrm{mmol} / \mathrm{L}: \mathrm{H} \\
\text { Lemershow: } 7.35, \mathrm{p}=0.499\end{array}$} \\
\hline Male gender & 2.1 & $1.5-2.9$ & $<0.001$ \\
\hline Body mass index & 0.97 & $0.94-0.997$ & $<0.05$ \\
\hline Retinopathy & 1.4 & $1.1-1.9$ & $<0.05$ \\
\hline $\begin{array}{l}\text { Peripheral occlusive } \\
\text { arterial disease }\end{array}$ & 2.5 & $1.6-3.8$ & $<0.001$ \\
\hline Mean blood pressure & 1.01 & $1.00-1.03$ & 0.01 \\
\hline $\begin{array}{l}\text { Atherogenic dyslipi- } \\
\text { demia }\end{array}$ & 1.8 & $1.0-3.3$ & 0.05 \\
\hline Smoking & & & NS \\
\hline \multicolumn{4}{|c|}{$\begin{array}{l}\text { Silent coronary artery disease in patients with } \mathrm{LDL}<3.35 \mathrm{mmol} / \mathrm{L} \text { : } \mathrm{H} \\
\text { Lemershow: } 5.30, \mathrm{p}=0.725\end{array}$} \\
\hline Male gender & 3.0 & $1.6-5.6$ & $<0.0001$ \\
\hline Body mass index & 0.94 & $0.90-0.995$ & $<0.05$ \\
\hline Retinopathy & 1.7 & $1.0-2.9$ & $<0.05$ \\
\hline Microalbuminuria & & & NS \\
\hline $\begin{array}{l}\text { Peripheral occlusive } \\
\text { arterial disease }\end{array}$ & 4.0 & $2.1-7.4$ & $<0.0001$ \\
\hline Mean blood pressure & 1.03 & $1.01-1.05$ & 0.001 \\
\hline $\begin{array}{l}\text { Atherogenic dyslipi- } \\
\text { demia }\end{array}$ & 4.0 & $1.7-9.2$ & 0.001 \\
\hline Smoking & & & NS \\
\hline \multicolumn{4}{|c|}{$\begin{array}{l}\text { Silent coronary artery disease in patients with } \mathrm{LDL}<2.6 \mathrm{mmol} / \mathrm{L}: \mathrm{H} \\
\text { Lemershow: } 12.85, \mathrm{p}=0.117\end{array}$} \\
\hline Male gender & 3.0 & $1.1-8.2$ & $<0.05$ \\
\hline Body mass index & & & 0.07 \\
\hline Retinopathy & & & 0.09 \\
\hline $\begin{array}{l}\text { Peripheral occlusive } \\
\text { arterial disease }\end{array}$ & 3.7 & $1.7-8.1$ & 0.001 \\
\hline Mean blood pressure & 1.03 & $1.00-1.06$ & $<0.05$ \\
\hline $\begin{array}{l}\text { Atherogenic dyslipi- } \\
\text { demia }\end{array}$ & 2.96 & $0.97-9.03$ & 0.057 \\
\hline Smoking & 2.2 & $1.1-4.4$ & $<0.05$ \\
\hline
\end{tabular}

factor to the residual burden of cardiovascular disease in patients with type 2 diabetes, in line with recent expert consensus [40].

In conclusion, the present study demonstrates that atherogenic dyslipidemia is associated with increased risk of both SMI and silent CAD in high-risk patients with type 2 diabetes, especially in those with LDL cholesterol lower than $3.35 \mathrm{mmol} / \mathrm{L}$. A patient screening taking this factor into account might help with an earlier identification of asymptomatic CAD. Since a significant part of the residual risk is related both to atherogenic dyslipidemia and silent coronary disease, targeting triglycerides and HDL cholesterol might be considered in patients with silent
Table 6 Characteristics of the patients with LDL cholesterol $<2.6 \mathrm{mmol} / \mathrm{L}$ according to the presence of asymptomatic coronary artery disease

\begin{tabular}{|c|c|c|c|c|}
\hline & $\begin{array}{l}\text { No CAD } \\
n=496\end{array}$ & $\begin{array}{l}\text { CAD } \\
n=45\end{array}$ & $\begin{array}{l}\text { Odds ratic } \\
{[95 \mathrm{Cl}]}\end{array}$ & \\
\hline \multicolumn{5}{|l|}{ Clinical characteristics } \\
\hline Age, years & $61.3 \pm 8.9$ & $61.1 \pm 8.4$ & & NS \\
\hline $\begin{array}{l}\text { Gender, male/ } \\
\text { female }\end{array}$ & $289 / 207$ & $39 / 6$ & $\begin{array}{c}4.7[1.9- \\
11.2]\end{array}$ & $<0.0001$ \\
\hline $\begin{array}{l}\text { Body mass index, } \\
\mathrm{kg} / \mathrm{m}^{2}\end{array}$ & $30.5 \pm 6.1$ & $27.6 \pm 3.7$ & & $<0.01$ \\
\hline \multicolumn{5}{|l|}{ Diabetes } \\
\hline $\begin{array}{l}\text { Diabetes duration, } \\
\text { years }\end{array}$ & $14.0 \pm 8.2$ & $12.6 \pm 7.5$ & & NS \\
\hline $\mathrm{HbA} 1 \mathrm{c}, \%$ & $8.4 \pm 1.9$ & $8.5 \pm 1.9$ & & NS \\
\hline Retinopathy, \% & $157(32.8)$ & $20(45.5)$ & & 0.09 \\
\hline Nephropathy, \% & $193(59.9)$ & $17(53.1)$ & & NS \\
\hline $\begin{array}{l}\text { Microalbuminuria } \\
>30 \mathrm{mg} / \text { day, } \%\end{array}$ & $151(35.4)$ & $16(39.0)$ & & NS \\
\hline $\begin{array}{l}\text { Creatinine clear- } \\
\text { ance, } \mathrm{ml} / \mathrm{min}\end{array}$ & $86.6 \pm 28.6$ & $84.8 \pm 26.2$ & & NS \\
\hline $\begin{array}{l}\text { Urinary albumin } \\
\text { excretion rate, } \\
\text { mg/day }\end{array}$ & $136.3 \pm 506.7$ & $139.1 \pm 228.3$ & & NS \\
\hline $\begin{array}{l}\text { Proteinuria, } \\
\text { g/day, } \%\end{array}$ & $0.4 \pm 1.0$ & $0.3 \pm 0.3$ & & NS \\
\hline $\begin{array}{l}\text { Peripheral neu- } \\
\text { ropathy, \% }\end{array}$ & $98(44.5)$ & $16(53.3)$ & & NS \\
\hline $\begin{array}{l}\text { Peripheral arterial } \\
\text { occlusive disease, } \\
\%\end{array}$ & $40(8.4)$ & $14(32.6)$ & $\begin{array}{l}5.3[2.6- \\
10.7]\end{array}$ & $<0.0001$ \\
\hline \multicolumn{5}{|c|}{ Additional cardiovascular risk factors } \\
\hline Hypertension, \% & $180(79.3)$ & $33(82.5)$ & & NS \\
\hline $\begin{array}{l}\text { Mean blood pres- } \\
\text { sure, } \mathrm{mmHg}\end{array}$ & $92.0 \pm 11.1$ & $96.3 \pm 11.4$ & & $<0.05$ \\
\hline $\begin{array}{l}\text { Atherogenic dys- } \\
\text { lipidemia, \% }\end{array}$ & $24(4.8)$ & $7(15.6)$ & $\begin{array}{l}3.6[1.5- \\
9.0]\end{array}$ & 0.01 \\
\hline \multicolumn{5}{|l|}{ Lipid parameters } \\
\hline $\begin{array}{l}\mathrm{HDL} \text { cholesterol, } \\
\mathrm{mmol} / \mathrm{L}\end{array}$ & $1.3 \pm 0.5$ & $1.1 \pm 0.3$ & & $<0.01$ \\
\hline $\begin{array}{l}\text { Triglycerides, } \\
\mathrm{mmol} / \mathrm{L}\end{array}$ & $1.7 \pm 1.0$ & $1.9 \pm 1.3$ & & NS \\
\hline $\begin{array}{l}\text { LDL cholesterol, } \\
\mathrm{mmol} / \mathrm{L}\end{array}$ & $2.0 \pm 0.4$ & $2.0 \pm 0.5$ & & NS \\
\hline $\begin{array}{l}\text { Non-HDL choles- } \\
\text { terol, mmol/L }\end{array}$ & $2.7 \pm 0.6$ & $2.9 \pm 0.7$ & & 0.224 \\
\hline $\begin{array}{l}\text { Apoprotein A1, } \\
\text { g/L }\end{array}$ & $1.46 \pm 0.30$ & $1.42 \pm 0.24$ & & 0.706 \\
\hline Apoprotein B, g/L & $0.80 \pm 0.16$ & $0.92 \pm 0.14$ & & 0.034 \\
\hline $\begin{array}{l}\text { Fibrate treatment, } \\
\%\end{array}$ & $38(7.9)$ & $5(11.1)$ & & NS \\
\hline Statin treatment, $\%$ & $250(51.7)$ & $24(53.3)$ & & NS \\
\hline Smoking, \% & $111(22.6)$ & $20(44.4)$ & $\begin{array}{l}2.7[1.5- \\
5.1]\end{array}$ & $<0.01$ \\
\hline
\end{tabular}

$C A D$ coronary artery disease 


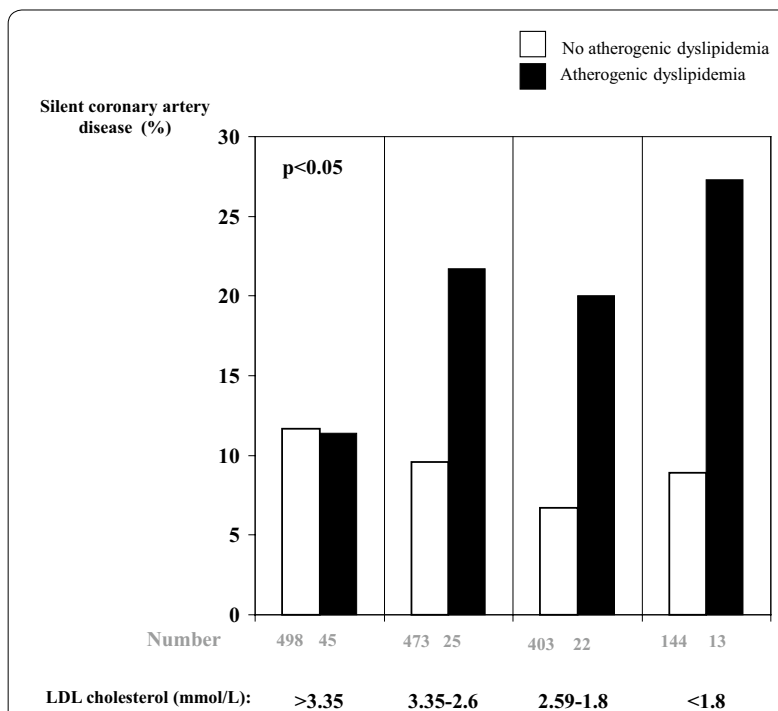

Fig. 1 Prevalence of silent coronary artery disease according to presence of atherogenic dyslipidemia and LDL cholesterol levels

CAD and such lipid disorders. However, our findings need to be confirmed by prospective studies conducted in larger series of patients with atherogenic dyslipidemia and with LDL cholesterol in the target range.

\section{Abbreviations}

CAD: coronary artery disease; SMI: silent myocardial ischemia; POAD: peripheral occlusive arterial disease.

\section{Authors' contributions}

PV and EC wrote manuscript. All authors researched data, contributed to the discussion and reviewed/edited the manuscript. MTN made the statistics. All authors read and approved the final manuscript.

\section{Author details \\ ${ }^{1}$ Department of Endocrinology-Diabetology-Nutrition, CRNH-IdF, CINFO, AP- HP, Jean Verdier Hospital, Université Paris 13, Sorbonne Paris Cité, Avenue du 14 Juillet, 93143 Bondy Cedex, France. ${ }^{2}$ Unité de Recherche Epidémiologique Nutritionnelle, UMR U1153 INSERM/U11125 INRA/CNAM/Université Paris 13, 93000 Bobigny, France. ${ }^{3}$ Department of Endocrinology-Diabetology-Nutrition, CHRU Montpellier, 34295 Montpellier Cedex 5, France. ${ }^{4}$ PhyMedExp, INSERM U1046, CNRS UMR 9214, University of Montpellier, 34295 Montpellier Cedex 5, France.}

\section{Acknowledgements}

No.

\section{Competing interests}

The authors declare that they have no competing interests.

Received: 1 March 2016 Accepted: 30 June 2016

Published online: 22 July 2016

\section{References}

1. Valensi P, Lorgis L, Cottin Y. Prevalence, incidence, predictive factors and prognosis of silent myocardial infarction: a review of the literature. Arch Cardiovasc Dis. 2011;104:178-88.
2. Wackers FJ, Young LH, Inzucchi SE, Chyun DA, Davey JA, Barrett EJ, Taillefer R, Wittlin SD, Heller GV, Filipchuk N, Engel S, Ratner RE, Iskandrian AE. Detection of silent myocardial ischemia in asymptomatic diabetic subjects: the DIAD study. Diabetes Care. 2004;27:1954-61.

3. Cosson E, Guimfack M, Paries J, Paycha F, Attali JR, Valensi P. Are silent coronary stenoses predictable in diabetic patients and predictive of cardiovascular events? Diabetes Metab. 2003;29:470-6.

4. Cosson E, Guimfack M, Paries J, Paycha F, Attali JR, Valensi P. Prognosis for coronary stenoses in patients with diabetes and silent myocardial ischemia. Diabetes Care. 2003;26:1313-4.

5. Valensi P, Paries J, Brul port-Cerisier V, Torremocha F, Sachs RN, Vanzetto G, Cosson E, Lormeau B, Attali JR, Marechaud R, Estour B, Halimi S. Predictive value of silent myocardial ischemia for cardiac events in diabetic patients: influence of age in a French multicenter study. Diabetes Care. 2005;28:2722-7.

6. Young LH, Wackers FJ, Chyun DA, Davey JA, Barrett EJ, Taillefer R, Heller GV, Iskandrian AE, Wittlin SD, Filipchuk N, Ratner RE, Inzucchi SE. Cardiac outcomes after screening for asymptomatic coronary artery disease in patients with type 2 diabetes: the DIAD study: a randomized controlled trial. JAMA. 2009;301:1547-55.

7. Cosson E, Nguyen MT, Chanu B, Banu I, Chiheb S, Balta C, Takbou K, Valensi P. Cardiovascular risk prediction is improved by adding asymptomatic coronary status to routine risk assessment in type 2 diabetic patients. Diabetes Care. 2011;34:2101-7.

8. Gaede P, Vedel P, Larsen N, Jensen GV, Parving HH, Pedersen O. Multifactorial intervention and cardiovascular disease in patients with type 2 diabetes. N Engl J Med. 2003;348:383-93.

9. Wei Y, Guo H, The E, Che W, Shen J, Hou L, Zhao S, Ye P, Li G, Wang D, Jie Q, Hu D. Persistent lipid abnormalities in statin-treated coronary artery disease patients with and without diabetes in China. Int J Cardiol. 2015;182:469-75.

10. Tenenbaum A, Klempfner R, Fisman EZ. Hypertriglyceridemia: a too long unfairly neglected major cardiovascular risk factor. Cardiovasc Diabetol. 2014;13:159.

11. Bittencourt C, Piveta VM, Oliveira CS, Crispim F, Meira D, Saddi-Rosa P, Giuffrida FM, Reis AF. Association of classical risk factors and coronary artery disease in type 2 diabetic patients submitted to coronary angiography. Diabetol Metab Syndr. 2014;6:46.

12. Klempfner R, Erez A, Sagit BZ, Goldenberg I, Fisman E, Kopel E, Shlomo $\mathrm{N}$, Israel A, Tenenbaum A. Elevated triglyceride level is independently associated with increased all-cause mortality in patients with established coronary heart disease: twenty-two-year follow-up of the bezafibrate infarction prevention study and registry. Circ Cardiovasc Qual Outcomes. 2016;9:100-8.

13. Miselli MA, Nora ED, Passaro A, Tomasi F, Zuliani G. Plasma triglycerides predict ten-years all-cause mortality in outpatients with type 2 diabetes mellitus: a longitudinal observational study. Cardiovasc Diabetol. 2014;13:135.

14. Sprandel MC, Hueb WA, Segre A, Ramires JA, Kali--Filho R, Maranhao RC. Alterations in lipid transfers to HDL associated with the presence of coronary artery disease in patients with type 2 diabetes mellitus. Cardiovasc Diabetol. 2015;14:107.

15. Eliasson B, Gudbjornsdottir S, Zethelius B, Eeg-Olofsson K, Cederholm J. LDL-cholesterol versus non-HDL-to-HDL-cholesterol ratio and risk for coronary heart disease in type 2 diabetes. Eur J Prev Cardiol. 2014;21:1420-8.

16. Eeg-Olofsson K, Gudbjornsdottir S, Eliasson B, Zethelius B, Cederholm J. The triglycerides-to-HDL-cholesterol ratio and cardiovascular disease risk in obese patients with type 2 diabetes: an observational study from the Swedish National Diabetes Register (NDR). Diabetes Res Clin Pract. 2014;106:136-44.

17. Milan Study on Atherosclerosis and Diabetes (MiSAD) Group. Prevalence of unrecognized silent myocardial ischemia and its association with atherosclerotic risk factors in noninsulin-dependent diabetes mellitus. Am J Cardiol. 1997;79:134-9.

18. Pham I, Nguyen MT, Valensi P, Rousseau H, Nitenberg A, Vicaut E, Cosson E. Noninvasive study of coronary microcirculation response to a cold pressor test. Eur J Clin Invest. 2015;45:135-43.

19. Gazzaruso C, Garzaniti A, Giordanetti S, Falcone C, De Amici E, Geroldi D, Fratino P. Assessment of asymptomatic coronary artery disease in apparently uncomplicated type 2 diabetic patients: a role for lipoprotein(a) and apolipoprotein(a) polymorphism. Diabetes Care. 2002;25:1418-24.

20. The ACCORD study group. Effects of combination lipid therapy in type 2 diabetes mellitus. N Engl J Med. 2010;362:1563-74. 
21. Carey VJ, Bishop L, Laranjo N, Harshfield BJ, Kwiat C, Sacks FM. Contribution of high plasma triglycerides and low high-density lipoprotein cholesterol to residual risk of coronary heart disease after establishment of low-density lipoprotein cholesterol control. Am J Cardiol. 2010;106:757-63.

22. Miller M, Stone NJ, Ballantyne C, Bittner V, Criqui MH, Ginsberg HN, Goldberg AC, Howard WJ, Jacobson MS, Kris-Etherton PM, Lennie TA, Levi M, Mazzone T, Pennathur S. Triglycerides and cardiovascular disease: a scientific statement from the American Heart Association. Circulation. 2011;123:2292-333.

23. Chapman MJ, Ginsberg HN, Amarenco P, Andreotti F, Boren J, Catapano $A L$, Descamps OS, Fisher E, Kovanen PT, Kuivenhoven JA, Lesnik P, Masana L, Nordestgaard BG, Ray KK, Reiner Z, Taskinen MR, Tokgozoglu L, Tybjaerg-Hansen A, Watts GF. Triglyceride-rich lipoproteins and high-density lipoprotein cholesterol in patients at high risk of cardiovascular disease: evidence and guidance for management. Eur Heart J. 2011;32:1345-61.

24. Keech A, Simes RJ, Barter P, Best J, Scott R, Taskinen MR, Forder P, Pillai A, Davis T, Glasziou P, Drury P, Kesaniemi YA, Sullivan D, Hunt D, Colman P, d'Emden M, Whiting M, Ehnholm C, Laakso M. Effects of long-term fenofibrate therapy on cardiovascular events in 9795 people with type 2 diabetes mellitus (the FIELD study): randomised controlled trial. Lancet. 2005:366:1849-61.

25. Diabetes Atherosclerosis Intervention Study Investigators. Effect of fenofibrate on progression of coronary-artery disease in type 2 diabetes: the diabetes atherosclerosis intervention study, a randomised study. Lancet. 2001:357:905-10

26. Arbel Y, Klempfner R, Erez A, Goldenberg I, Benzekry S, Shlomo N, Fisman EZ, Tenenbaum A. Bezafibrate for the treatment of dyslipidemia in patients with coronary artery disease: 20-year mortality follow-up of the BIP randomized control trial. Cardiovasc Diabetol. 2016;15:11.

27. Avignon A, Sultan A, Piot C, Mariano-Goulart D, Thuan Dit Dieudonne JF, Cristol JP, Dupuy AM. Osteoprotegerin: a novel independent marker for silent myocardial ischemia in asymptomatic diabetic patients. Diabetes Care. 2007;30:2934-9.

28. Fruchart JC, Sacks FM, Hermans MP. Implications of the ACCORD lipid study: perspective from the Residual Risk Reduction Initiative (R(3)i). Curr Med Res Opin. 2010;26:1793-7.

29. Leiter LA, Lundman P, da Silva PM, Drexel H, Junger C, Gitt AK. Persistent lipid abnormalities in statin-treated patients with diabetes mellitus in Europe and Canada: results of the Dyslipidaemia International Study. Diabet Med. 2011;28:1343-51

30. Cabrera M, Sanchez-Chaparro MA, Valdivielso P, Quevedo-Aguado L, Catalina-Romero C, Fernandez-Labandera C, Ruiz-Moraga M, GonzalezSantos P, Calvo-Bonacho E. Prevalence of atherogenic dyslipidemia: association with risk factors and cardiovascular risk in Spanish working population. "ICARIA" study. Atherosclerosis. 2014;235:562-9.

31. Valensi P, Picard S. Lipids, lipid-lowering therapy and diabetes complications. Diabetes Metab. 2011;37:15-24.

32. Fruchart JC, Davignon J, Hermans MP, Al-Rubeaan K, Amarenco P, Assmann G, Barter P, Betteridge J, Bruckert E, Cuevas A, Farnier M, Ferrannini E, Fioretto P, Genest J, Ginsberg HN, Gotto AM Jr, Hu D, Kadowaki T, Kodama T, Krempf M, Matsuzawa Y, Nunez-Cortes JM, Monfil CC, Ogawa H, Plutzky J, Rader DJ, Sadikot S, Santos RD, Shlyakhto E, Sritara P, Sy R, Tall A, Tan CE, Tokgozoglu L, Toth PP, Valensi P, Wanner C, Zambon A, Zhu J, Zimmet P. Residual macrovascular risk in 2013: what have we learned? Cardiovasc Diabetol. 2014;13:26.
33. Di Bonito P, Moio N, Scilla C, Cavuto L, Sibilio G, Sanguigno E, Forziato C, Saitta F, lardino MR, Di Carluccio C, Capaldo B. Usefulness of the high triglyceride-to-HDL cholesterol ratio to identify cardiometabolic risk factors and preclinical signs of organ damage in outpatient children. Diabetes Care. 2012;35:158-62.

34. Mahalle N, Garg MK, Naik SS, Kulkarni MV. Study of pattern of dyslipidemia and its correlation with cardiovascular risk factors in patients with proven coronary artery disease. Indian J Endocrinol Metab. 2014;18:48-55.

35. Faglia E, Manuela M, Antonella Q, Michela G, Vincenzo C, Maurizio C, Roberto M, Alberto M. Risk reduction of cardiac events by screening of unknown asymptomatic coronary artery disease in subjects with type 2 diabetes mellitus at high cardiovascular risk: an open-label randomized pilot study. Am Heart J. 2005;149:e1-6.

36. Gazzaruso C, Coppola A, Montalcini T, Valenti C, Pelissero G, Solerte SB, Salvucci F, Gallotti P, Pujia A, Garzaniti A, Giustina A. Screening for asymptomatic coronary artery disease can reduce cardiovascular mortality and morbidity in type 2 diabetic patients. Intern Emerg Med. 2012;7:257-66.

37. Muhlestein JB, Lappe DL, Lima JA, Rosen BD, May HT, Knight S, Bluemke DA, Towner SR, Le V, Bair TL, Vavere AL, Anderson JL. Effect of screening for coronary artery disease using CT angiography on mortality and cardiac events in high-risk patients with diabetes: the FACTOR-64 randomized clinical trial. JAMA. 2014;312:2234-43.

38. Burgess DC, Hunt D, Li L, Zannino D, Williamson E, Davis TM, Laakso M, Kesäniemi YA, Zhang J, Sy RW, Lehto S, Mann S, Keech AC. Incidence and predictors of silent myocardial infarction in type 2 diabetes and the effect of fenofibrate: an analysis from the Fenofibrate Intervention and Event Lowering in Diabetes (FIELD) study. Eur Heart J 2010;31:92-9.

39. Sacks FM, Carey VJ, Fruchart JC. Combination lipid therapy in type 2 diabetes. N Engl J Med. 2010;363:692-4 (author reply 4-5).

40. Aguiar C, Alegria E, Bonadonna RC, Catapano AL, Cosentino F, Elisaf M, Farnier M, Ferrieres J, Filardi PP, Hancu N, Kayikcioglu M, Mello ESA, Millan J, Reiner Z, Tokgozoglu L, Valensi P, Viigimaa M, Vrablik M, Zambon A, Zamorano $J$, Ferrari R. A review of the evidence on reducing macrovascular risk in patients with atherogenic dyslipidaemia: a report from an expert consensus meeting on the role of fenofibrate-statin combination therapy. Atheroscler Suppl. 2015;19:1-12.

41. Reiner Z, Catapano AL, De Backer G, Graham I, Taskinen MR, Wiklund $\mathrm{O}$, Agewall S, Alegria E, Chapman MJ, Durrington P, Erdine S, Halcox J, Hobbs R, Kjekshus J, Filardi PP, Riccardi G, Storey RF, Wood D. ESC/EAS Guidelines for the management of dyslipidaemias: the Task Force for the management of dyslipidaemias of the European Society of Cardiology (ESC) and the European Atherosclerosis Society (EAS). Eur Heart J. 2011;32:1769-818.

\section{Submit your next manuscript to BioMed Central and we will help you at every step:}

- We accept pre-submission inquiries

- Our selector tool helps you to find the most relevant journal

- We provide round the clock customer support

- Convenient online submission

- Thorough peer review

- Inclusion in PubMed and all major indexing services

- Maximum visibility for your research

Submit your manuscript at www.biomedcentral.com/submit
BioMed Central 